\title{
A trajetória de Agustin Cueva
}

\section{MARIA LÍGIA COELHO PRADO}

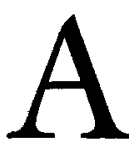

gustin Cueva Dávila, sociólogo equatoriano, morreu no dia 19 de maio de 1992, vítima de câncer. Nestes tempos difíceis, nos quais na América Latina os sonhos de uma transformaçáo radical se evaporaram e as utopias socialistas estão fora de moda e em descendente popularidade, Agustin Cueva foi daqueles intelectuais que até o fim de sua vida manteve-se fiel às suas crenças políticas e ideológicas. Ainda que nunca tivesse se filiado a um partido de esquerda, sua formação maoísta (de juventude) jamais o abandonou inteiramente, embora tenha se matizado em sua idade madura. Crítico da burocracia e do dogmatismo dos Partidos Comunistas latino-americanos, caracterizou-se, entretanto, por posição militante antitrotskista.

Em uma de suas recentes estadas no Brasil, a convite do Instituto de Estudos Avançados da Universidade de São Paulo, em 1989 (1), tinha em mãos manuscrito sobre o avanço e o êxito crescentes da direita no mundo. Este foi o tema que dominou suas preocupações intelectuais e políticas nos últimos anos. Como sinal desses Tempos Conservadores, (título que o manuscrito posteriormente recebeu), vinha encontrando dificuldades para publicá-lo em espanhol.

Nasceu em 1937, em Ibarra, Equador, de uma família de liberais politicamente influentes; seu tio-avô foi presidente da República e seu pai, Agustin Cueva Sanz, considerado por muitos como o introdutor da sociologia no Equador, foi deputado à Assembléia de 1929, propondo várias leis que beneficiavam os índios e os trabalhadores pobres. Augustin teve formaçăo acadêmica tradicional, diplomando-se em Direito; interessado por política, literatura e sociologia, acabou por iniciar uma carreira acadêmica na Universidade Central do Equador.

Já como diretor da Escola de Sociologia foi convidado, algumas vezes, para ministrar cursos na Universidade de Concepción, no Chile; numa dessas visitas, em 1972, aconteceu no Equador o golpe militar que impediu a provável eleiçáo de Velasco Ibarra. Dessa maneira, estava vedada, por razóes políticas, a volta de Agustin a seu país e decidida sua permanência no Chile. $O$ destino the preparava mais uma surpresa; 
quando participava de um congresso no México, em setembro de 1973, Pinochet derrubou Allende do poder. Essa série de acontecimentos inesperados determinou sua permanência no México. Se, anteriormente, havia se dedicado a trabalhar sobre seu país natal, essa peregrinação transformou-o num intelectual que passou a refletir sobre a América Latina, ampliando e tornando mais complexas suas indagaçóes sobre a política e a cultura. Percorreu ele, assim, caminho comum a tantos outros intelectuais de esquerda na América Latina das últimas décadas. Sua vivência diversificada mostrou-lhe, como gostava de afirmar, existir na América Latina identidade de problemas políticos e de busca de soluçóes comuns, que justificam as análises abrangentes sobre a regiâo. Além disso, entendia ser possível encontrar no continente, a despeito de todas as diversidades, certa maneira particular de entender e de produzir cultura.

Sua produção acadêmica pode ser dividida em duas partes: a primeira, em que ele analisou a cultura e a política do Equador e, a segunda, na qual estudou a América Latina. Sáo da primeira fase, Entre la ira y la esperanza, de 1967, que discute temas da cultura nacional e uma série de ensaios sociológicos sobre literatura, publicados esparsamente nos anos 60 e 70, reunidos, em 1986, no livro Lecturas y rupturas. Particularmente interessantes são as análises sobre Jorge Icaza e sobre a literatura indigenista do Equador. El processo de dominación política en el Ecuador, de 1972, é uma análise histórica da luta pelo poder político no século $\mathrm{XX}, \mathrm{e}$, também, um ensaio de interpretaçáo sobre Velasco Ibarra, em que aponta os passos da construção do mito em torno desse personagem. $O$ livro, considerado um clássico da produção sociológica equatoriana, teve até o presente onze ediçóes em espanhol, além de ter sido traduzido para $o$ inglês.

Agustin Cueva, entretanto, ficou conhecido na América Latina com o trabalho El Desarrollo del Capitalismo en América Latina, Prêmio Ensaio Siglo XXI de 1977, e que já ultrapassou a 10a edição em espanhol, traduzido para japonês, holandês e português. Um livro que, sem dúvida, em sua análise sobre o desenvolvimento do capitalismo, inspirou-se em sua experiência andina - a Serra equatoriana -, onde as relaçōes de trabalho mantêm, ainda neste século, algumas formas bastante tradicionais de organização. Assim, pode-se entender melhor sua utilização do conceito de acumulaçáo primitiva do capital, aplicado às sociedades latino-americanas. Sua interpretaçáo traz implícita uma crítica à teoria da dependência, mas combina perfeitamente com a valorização do conceito de imperialismo e com a insistência na temática da luta de classes. À época de sua publicaçăo, constituiu um livro estimulante, que despertou 
polêmicas, produziu defensores e críticos ardorosos e influiu em muitas interpretaçōes historiográficas.

Essa inquietaçáo pelos problemas contemporâneos da América Latina levou-o a publicar, em 1979, Teoria Social y Procesos Políticos en América Latina, no qual faz revisão crítica da sociologia marxista latinoamericana dos anos 60 e 70, e analisa os regimes militares de Brasil, Argentina, Uruguai e Chile, por ele entendidos como facistas. Tempos Conservadores, que ele organizou e era parte de um grande projeto de pesquisa, foi publicado no Equador em 1987 e, posteriormente, no Brasil. Congrega artigos de vários intelectuais, tratando do avanço da direita no mundo e da derrocada da esquerda. Um texto de alerta em que Cueva buscava denunciar o conservadorismo mundial crescente, procurando localizar a América Latina nesse contexto global.

Agustin Cueva acreditava no intelectual engajado politicamente e que pretendia, com seu trabalho, contribuir para a causa do socialismo, pois este era, na sua visão, a melhor solução para os problemas sociais e econômicos latino-americanos. Jamais afastou-se dessas idéias, o que para alguns, particularmente, nestes últimos anos, foi motivo de crítica. Ao lado das polêmicas que manteve durante toda sua vida com os trotskistas, mais recentemente, foi acusado, entre outros, por José Aricó, de não haver conseguido libertar-se do marxismo mais ortodoxo. Entretanto, o importante a ser aqui registrado, é a repercussão de sua obra no continente e sua contribuiçáo para uma reflexão crítica sobre a história contemporânea da América Latina.

Antes de terminar, gostaria de fazer algumas referências pessoais a Agustin Cueva, pois, antes de tudo, era um querido amigo. Homem amável, generoso, um cavalheiro à moda antiga, com extraordinárias inquietação e curiosidade intelectuais, sempre aberto a conhecer novas experiências culturais. Seu casamento com Terezinha Bertussi, socióloga brasileira radicada no México, levou-o a incorporar o Brasil em sua reflexão sobre a América Latina, fato bastante raro entre os intelectuais hispano hablantes. Guardo de nossas conversas sobre o Brasil e o continente latino-americano, recordaçóes muito vivas e afetuosas.

Finalizo esta nota de homenagem, salientando aquilo que me parece fundamental. Agustin Cueva manteve viva a tradição latino-americana de um pensamento de esquerda, crítico ao sistema capitalista. Trabalhou sempre com a dimensão utópica do futuro, no qual as sociedades seriam mais justas, mais igualitárias e menos opressoras. Creio que sua vida e obra são, neste sentido, paradigmáticas. Poderia, se assim o desejasse, pelas suas relaçóes de família e formação intelectual, ter conseguido altos 
postos e honrarias oficiais junto ao governo equatoriano. Optou, entretanto, por uma vida no exílio - a nostalgia do Equador nunca o abandonou - em que se manteve integro, vivendo coerentemente com suas idéias, mantendo completa independência de pensamento e lutando, com suas armas, por aquilo em que acreditava.

\section{Nota}

O cientista político Agustin Cueva Dávila foi professor visitante do Instituto de Estudos Avançados no período de maio a junho de 1987.

Maria Ligia Coelho Prado é professora da Faculdade de Filosofia, Letras e Ciências Humanas da USP. 